\title{
INTRODUCTION TO THE ORIGINAL 1948 RUSSIAN EDITION
}

This book, Partisan Brotherhood, offered for the reader's attention, tells of the struggle of the Soviet people during the Great War for the Fatherland which our country fought against fascist Germany. This was a war engaged in behind enemy lines, in territories temporarily conquered by Hitler's soldiers.

Basically, Partisan Brotberbood contains material about the military activities of Jewish partisans, and was collected by the Jewish Anti-Fascist Committee of the USSR. The collection consists of memoirs of former commanders and commissars of partisan units as well as testimonies written by Soviet writers. They tell of various events in the "partisan war" and give individual profiles of partisan heroes and heroines. Despite its varied sources, Partisan Brotherhood is a unified work. All the accounts included in this book are concerned with a single subject: namely, the friendship and unity of the Soviet people, a friendship which took shape at the very beginning of the 1917 October Revolution, was strengthened during the terrible days of the Civil War following the revolution, and which found its fullest expression in the Great War for the Fatherland against the German conquerors.

At the start of the war, during the first difficult days for our country, Comrade Stalin, in his historic Moscow speech of November 6,1941, at a gathering of the Council of Workers Delegates, said:

The Germans built their war plans on the instability of the Soviet rear guard, and on the assumption that, following the first failure of the Red Army, conflict would break out between the workers and the farmers, and a division would take place among the peoples of the USSR. They thought that rebellion would spread and that the state would be split into factions. This would have facilitated the advance of the German conquerors up to the Ural Mountain passes. But 
the Germans made a grave error! The failures of the Red Army did not weaken, on the contrary, they strengthened the bond between the workers and the farmers, and intensified the friendship among the peoples of the USSR. Furthermore, they transformed the family of the peoples of the USSR into one strong camp which supported its Red Army and Red Navy with devotion.

The unity of the Soviet people was expressed with extraordinary courage during the war against the Nazis. Soviet people from all nationalities fought in partisan units, as well as within the lines of the Red Army. Those Soviet patriots who were left in territory conquered by the enemy, and who were able to take up arms, joined the partisans and fought bravely and devotedly for the honor, freedom and independence of their homeland. In the front lines, these "avengers of the people" included, together with the Russians: Ukrainians, Byelorussians, Jews, Georgians (Gruziny), Armenians, Latvians, Uzbeks, and members of other Soviet nationalities. All of them saw themselves as belonging to a single fighting partisan force.

These "avengers of the people" fought against the enemy and presented a model of brotherhood and friendship, of spiritual and ideological unity, among people who felt themselves as equals within their Soviet homeland. The struggle of the Jewish partisans against the Nazis is presented in this book as part of the overall struggle of all of the Soviet people, who rose as one to defend their country.

Shoulder-to-shoulder with partisans of other nationalities, the Jewish partisans fought against the Germans. They blew up bridges, destroyed military transports, wiped out reinforcements of the German Army, killed its officers and soldiers, and, with unyielding hatred, swept away the Nazi filth.

This book reveals only a few pages of the partisan struggle of the Soviet people. In this close-knit Soviet family, the Soviet Jews were loyal members, helping to protect the achievements of the Socialist Revolution.

October 9, 1948 


\section{Editor's Note}

It is important to make a few comments regarding the style and rhetoric of this introduction. There is no question that the Soviet people engaged in a heroic struggle against the Nazis. They fought bravely and endured great losses; however, the Soviet peoples were not always the "close-knit family" they are portrayed as; they did not always present a "model of brotherhood and friendship, of spiritual and ideological unity." This was especially true during the early phases of the war when some Soviet nationalities, the Ukrainians and Latvians, for example, openly welcomed the Nazis, hoping that a German victory would liberate them from Soviet rule. However, the German occupation was often so brutal that it pushed these nationalities back into the waiting arms of the USSR. The role of the Jews within the partisan and regular army units is accurate; Jews placed fourth in the number of participants within these units, behind the Russians, Ukrainians, and Byelorussians. Despite occasional anti-Semitism within the partisan groups, Jews did play a significant role in the war. To demonstrate this fact is the true intent of this book, despite the rhetoric that appears. 


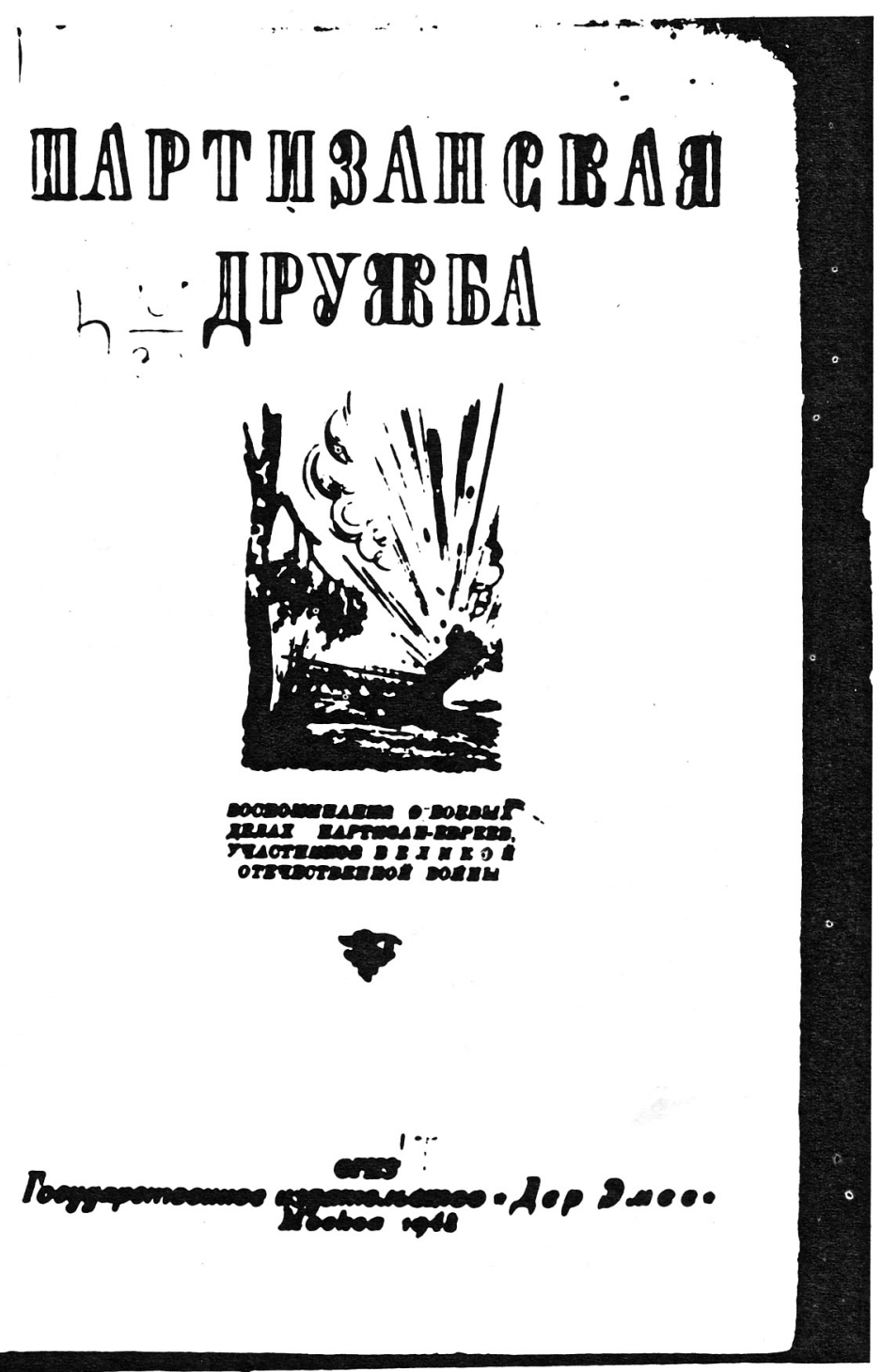

Facsimile of Russian original of the book, Partizanskaya Druzhba

Source: Lenin Library-Moscow Taken

from microfilm copy 


\section{O II E P i A H $\mathrm{E}$}

Om univame lucman

ВОСНОМИНАНИЯ

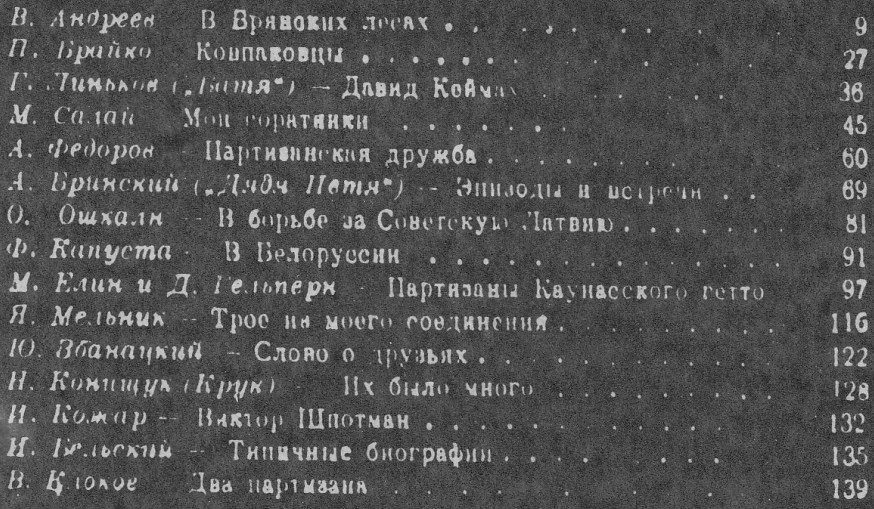

O 4 EIRH

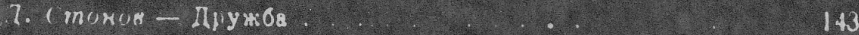

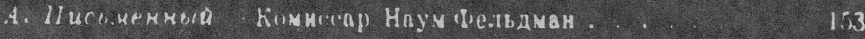

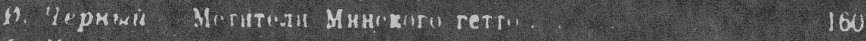

(. Ilomon B U.torclinx ratakunoux 167

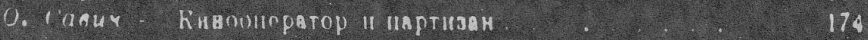

1. bоркин Cова Iутино 184

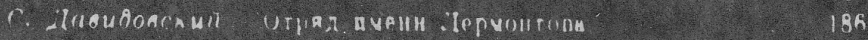

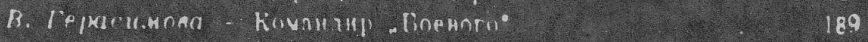

Facsimile of Russian original Table of Contents of the book, Partizanskaya Druzhba 
